\title{
Gender Discourse Analysis on Intergender Miscommunication between Carrie and Big in Sex and the City (2008)
}

\author{
Wensi Xue \\ School of Foreign Languages of Shaanxi Normal University \\ Xi'an 710062, China \\ E-mail: diana1985xue@sina.com
}

\begin{abstract}
Misunderstanding between men and women in intergender communication is quite common in daily life, which usually leads to an embarrassing situation. The purpose for this paper is to analyze typical gender discourses on misunderstandings between the hero and the heroine, and the potential sources of intergender miscommunication.
\end{abstract}

Keywords: Misunderstanding, Intergender communication, Gender discourses, Intergender miscommunication

\section{Introduction}

Day-to-day communication take place everywhere in our social life, but "language is ambiguous by nature" (Levinson, 1990) and "because of different assumptions they make as regards the purposes or goals of their communication" (Tannen, 1990a), miscommunication as well. And as the starring role playing in human beings' society, men and women will be the target of our study what we call gender discourse analysis, and intergender miscommunication analysis in specific. In this paper, three typical discourses extracted from movie dialogues in Sex and the City (2008) between the hero (Big) and the heroine (Carrie) will be analyzed on misunderstandings of specific words and the potential sources of intergender miscommunication in two aspects: differences in interpretive frames and social roles between men and women.

\section{Gender Discourse Analysis on Intergender Miscommunication between Carrie and Big}

Sex and the City is a 2008 American romantic comedy movie about four female friends: Carrie Bradshaw, Samantha Jones, Charlotte York Goldenblatt, and Miranda Hobbes, dealing with their lives as forty-something year olds in New York City. It portrays frank discussions about romance and sexuality. Therefore, it is clear that this movie targeted at men and women will be a typical one to study gender discourse. Specifically, we may see a segment of a whole gender discourse system by analyzing intergender miscommunication between Carrie and Big through their typical dialogues.

\subsection{Story Summary and Typical Discourses}

After deciding to move in together in a penthouse in Manhattan, Carrie and Big make a rather arbitrary decision to get married. The wedding itself proves to be a hasty affair-Carrie is given a Vivienne Westwood wedding gown after modeling it for a photo shoot in Vogue about marriage of women in their 40 - the guest list quickly blooms from 75 to 200, and her label-less wedding dress gives way to that fancy gown. Big begins to experience doubts on such a lavish event.

She: Okay, wedding crunch time. We need to get really serious here.

$H e$ : Okay, not now. I just get an e-mail from our contractor. He's pushed the move-in date yet again. I gotta write this guy and...

She: No, no, no, no. Wedding before contractor, all right? Unless you're planning to invite him which would make the guest list 201.

He: 200? Jesus, Carrie, it went up again?

She: It's the dress.

He: You said 75 people.

She: How can I explain this? Look... you play poker, right? Well, the dress upped the ante. (Big sighs.) How you doing on your vows? Now just to remind you. You'll be saying these in front of a lot of people, so the pressure is really on. 
$H e$ : Hey, I don't have time for this.

She: You're not taking it seriously.

$H e$ : No, no, I'm not. It is a circus. 200 people? Page 6? This is my third marriage. How do you think that makes me look?

She: I didn't know that was even an issue. So why didn’t you say anything sooner?

$H e$ : You wanted all of this.

She: Well, yeah. But don't you want...?

$H e$ : I want you. That's what I want. I could have just gone down to city hall.

On the eve of the big day, in the rehearsal dinner, the upset Miranda whose

husband Steve has cheated on her once tells Big that marriage ruins everything. With a complicated mood, Big calls Carrie at the all-gal sleepover night.

She: Hello.

$H e$ : Hello. It's me. I need to talk. I'm sitting here trying to write these vows and... Is this something we really wanna do?

She: What's the matter?

$H e$ : It's just... everything is great as it is. I don't wanna screw it up.

She: You won't.

$H e$ : I screwed it up twice before.

She: Here is the thing. This is me you're marrying tomorrow. Me. It's nobody else.

$H e$ : Yeah?

She: And I'm marrying you. It's me and you. And do you wanna hear the great news there?

He: Yeah.

She: We've both already done everything we can to screw it up. (Big forces a smile) Is that a smile I'm hearing?

$\mathrm{He}$ : Yeah.

She: It sounds to me like... you've got a bit of writer's block on the vow front.

$\mathrm{He}$ : Yeah.

She: And I find, you know, as a professional writer that it's best to just, you know just stop thinking about it so much and go to bed. And in the morning...

$H e$ : You'll know what to do.

She: Exactly. And if not then... Just write this: I will love you. Simple, to the point and I swear I won't even try to take credit for it. So you're gonna go to bed now, right?

$H e$ : Okay. Good-night.

She: I'll see you tomorrow. And hey... It's me and you.

On the day of the ceremony, Big doesn't show his face. Carrie calls him in a fluster.

He: Hello.

She: Are you okay?

$H e$ : I've been calling for an hour. Why haven't you been answering the phone?

She: Because I don't know where my phone is! So, what's going on? Where are you?

$H e$ : I was out front. I just left. I can't do this.

She: Oh my god...

$\mathrm{He}$ : Carrie? Carrie?

Then the humiliated Carrie flees the wedding and furiously attacks Big with her bouquet when he realizes he is screwing up Carrie's dream and changes mind. Well, what are the problems? Actually, misunderstandings in intergender miscommunication are the point. 


\subsection{Analysis on Misunderstandings between Carrie and Big in the Dialogues}

Both Carrie and Big feel confused and frustrated in three dialogues by mixing up two major things: wedding and marriage.

In the $1^{\text {st }}$ one, he says: "I don't have time for this." For his part, "this" means the vows she mentioned before. The surface meaning for it means he is busy in their contractor and has no time to write the vows. In fact, he uses it as an excuse to avoid the vows. What he really want to say is "I don't wanna write this stuff even say them in the public." For Carrie, no vows no wedding - sincere vows symbolize the strength of their relationship - she responds: "You are not taking it seriously." She actually complains that "You are not seriously taking our wedding (even the fact you will marry me)." That's why she asks him: "So why didn't you say anything sooner?" She thinks that he doesn't really want to marry her before the hasty decision. However, he is still talking about the vows and the lavish wedding as he answers: "You wanted all of this." She misunderstands "this" as "getting married" this time, so she doubts if he really wants to marry her. He tells her: "I want you. That's what I want. I could have just gone down to city hall." Now, we have no doubts about his marriage motivation-he just hopes it can be in a simple way.

In the $2^{\text {nd }}$ one, he says: "I'm sitting here trying to write these vows and... Is this something we really wanna do?" "This" here for him still means the vows in 200 -guest wedding, but her doubts come out again after hearing this. He explains that everything is great as it is and he doesn't want to screw it up. He intends to tell her that he doesn't want to screw up the perfect wedding as she plans so far and to let her down because of his unwillingness to say the vows in public, so he drops a hint that she would better cancel the plan. However, she misunderstands his words as that his doing not very well in the vows may screw up the perfect wedding. That's why she comforts him by saying "You won't." Then he says: "I screwed it up twice before." He tries to indicate that he has vowed twice during his last two weddings but neither of them has been realized. "It" here still means the vows, but she takes it as "marriage" another time. She then emphasizes that "This is me you're marrying tomorrow. Me. It's nobody else." - in order to tell him that his two divorcements due to marrying some other women not her, but this time tragedies won't happen because of the bride herself. Moreover, she emphasizes twice "It's me and you" which means marriage relationship between Big and herself for her part but the number of people to attend the wedding for his part. And the biggest misunderstanding for Carrie to Big is that she believes that his problem is writer's block on the vows, but the real one lies in saying vows in the lavish wedding.

In the $3^{\text {rd }}$ one, misunderstanding continues in the same way and even worse. She confirms her doubt that he doesn't really want to marry her and scares to face her at the very moment, although he does want to marry her but just in a different way by saying: "I can't do this"- only means "I have no courage to say the vows in front of 200 people."

\subsection{Analysis on Potential Sources of Intergender Miscommunication between Carrie and Big}

Carrie and Big in discourses above approach the same situation but misunderstand each other in different ways, mainly because "men and women have different interpretive frames and this leads them to draw the wrong inferences from language which in another situation would be quite clear and unambiguous. (Scollon, 2000)" Furthermore, the different roles men and women are playing in the society should also be taken into consideration. Two aspects of potential sources of intergender miscommunication between Carrie and Big will be discussed as follows:

\subsubsection{Differences in Interpretive Frames between Men and Women}

According to Tannen (1990a), there are 9 closely related dimensions that men and women tend to form different interpretive frames, they are:

1. intimacy-independence;

2. connection-status;

3. inclusive-exclusive;

4. relationship-information;

5. rapport-report;

6. community-contest;

7. problems-solutions;

8. novice-expect; 
9. listening-lecturing.

To meet the needs, we will mainly discuss two of them:

\subsubsection{Problems-Solutions}

One of the reasons of intergender miscommunication between Carrie and Big dues to the misunderstanding on the vows (extend to the wedding) and their marriage. As the $1^{\text {st }}$ and the $2^{\text {nd }}$ discourse present that Big doesn't want to write and say vows in the wedding and he rings her up to express himself in an indirect way, but what he does is just in vain - she adopts what Tannen (1990a) calls "troubles talk", the discussion of problems.

The reason why Carrie and Big take this different position is because "women tend to respond to hearing of someone else's problems by telling of their own problems. This indicates that they understand the situation the other person is in and that they feel sympathetic; men, in contrast, are more likely to take it as a request for help and to offer a solution, however pointless the solution might be. (Scollon, 2000)" The real purpose for Big is to get rid of the vows, but because of miscommunication she just shares her own feelings about dealing with such problem (writer's block) but no possible solutions as he wants. Therefore, when Big brings up his problem with Carrie, he is looking for some active discussion of possible solutions rather than a sympathetic ear and "troubles talk". "If she keeps doing that, they will never get anywhere in their discussion. He sooner or later gives up, thinking that she is illogical and cannot keep her mind on the subject, his subject. (Scollon, 2000)" In this situation, Big gives up at last to avoid hurting Carrie.

\subsubsection{Relationship-Information}

Another misunderstanding between Carrie and Big lies in her sentence- "It's me and you" which Carrie speaks twice. It emphasizes marriage relationship between Big and herself for her part, but the number of people to attend their wedding in his part.

Generally, because "women are concerned with intimacy, connection, and inclusion, they will tend to focus more attention on the use of language as a way of communicating relationships. Men, on the other hand, because of their focus on independence, status, and exclusion, will favor the informational functioning of language. (Scollon, 2000)" As a result, women tend to focus more on relationships than men, who tend to direct their attention to information. That's why Big responds: "Yeah?" in a doubtful tone when Carrie says: "Me. It's nobody else."- - for Big however, the fact is not really just "me and you" as the information conveys.

\subsubsection{Differences in Social Roles between Men and Women}

The Scollons (2000) displays that "not only do men and women work within very different interpretive frames of discourse in the home, but in professional communication those different ways of seeing the world are a major source of miscommunication, to the frustration and loss of everyone involved in them." Now it seems that professions or we may extend this to roles men and women are playing in the society should also be considered on this subject. Particularly, two dimensions of roles for Carrie and Big are discussed below:

\subsubsection{1 "The Last Single Girl” — Mr. Big in His Third Wedding}

Carrie is in her 40 when they decide to get married after 10-year hanging out. She is given a miserable name as "the ultimate single girl" in the newspaper or "the last single girl" in Vogue's special edition on marriage of women in their 40. Big, in contrast, is Mr. Big in his $3^{\text {rd }}$ wedding. Different roles result in different expectations. Therefore, Carrie has a thirst for marriage to end her loneliness for one reason, and for another, the most crucial thing is that without marriage she would have no legal rights to their penthouse in the event of a separation. As a result, a lavish wedding by all her own means is created. However, Big scares to behave as what Carrie expects for he would be teased like a clown in circus saying his $3^{\text {rd }}$ vows in front of 200 guests.

\subsubsection{A Best-Selling Writer-A New York Financier}

Carrie is a best-selling writer on themes of love - the sensational news about her happy ending comes around with legs - carried on the Page 6 and photographed for Vogue. Big, John James Preston actually, being called Big by Carrie's friends is because he is a real Mr. Big of financial area in New York City. Both of them have high status in the society. Consequently, Carrie believes that her photo shoot in Vogue and the wedding gown given by Vivienne Westwood deserve a perfect wedding, and the worst thing is that the whole world has known that Carrie Bradshaw is kissing good-bye to her single years. A failure in wedding (as important as marriage for her) would be a failure in reputation, that's why she is terribly anxious about her marriage and it leads to misunderstandings as a result. For the Mr. Big, the embarrassing behavior in the lavish wedding would be a threat for his status, so it is reasonable for his unwillingness to risk being teased in his $3^{\text {rd }}$ wedding by 200 people, or even more. 


\section{Conclusion}

Now we can draw a conclusion that the discourse of men and women does form two systems that are in many ways distinct from each other by which intergender miscommunication occurs inevitably. However, correctly learning and objectively analyzing gender discourses on differences between men and women would be an effective way to reduce misunderstandings and increase understandings in intergender communication. Furthermore, no matter what types of communication and how complicated they are, trying to put oneself in others' place to realize what he or she is feeling and trying to do would always work.

\section{References}

Levinson, Stephen C. (1990). Interactional biases in human thinking. Working Paper No. 3, Project Group Cognitive Anthropology, Max-Planck-Gesellschaft, Berlin.

Scollon, Ron and Suzanne Wong Scollon. (2000). Intercultural Communication: A Discourse Approach. Beijing: Foreign Language Teaching and Research Press. Oxford: Blackwell Publishers Ltd. 6, 229-237.

Tannen, Deborah. (1990a). You Just Don't Understand: women and men in conversation. New York: William Morrow.

Wikipedia: Sex and the City (film). [Online] Available: http://en.wikipedia.org/wiki/Sex_and_the_City_(film) (July, $\left.1^{\text {st }}, 2010\right)$. 